\section{Treatment with octreotide to suppress corticotropin secretion by a carcinoid tumour}

\section{Eugenia B Tirovola ${ }^{1}$ James S Malpas ${ }^{2}$}

\section{J R Soc Med 2005;98:516}

Ectopic secretion of corticotropin (ACTH) by a tumour is most likely to respond to somatostatin analogues if hypercortisolaemia has not yet developed.

\section{CASE HISTORY}

A man aged 73 with type 2 diabetes (treated with metformin) sought advice after five months of flushing and a $10 \mathrm{~kg}$ gain in weight. Clinically he had ascites and this was confirmed by CT. No other abnormalities were seen radiographically but on drainage the fluid contained malignant cells. Barium enema revealed stenosis in the sigmoid colon, and segmental resection yielded two small tumours of carcinoid type $(2.6 \mathrm{~cm}$ and $1.0 \mathrm{~cm})$, staining positive for neurospecific enolase and ACTH with metastatic involvement of fatty tissue and peritoneum. Three months postoperatively he was still experiencing flushing. Urine 5-hydroxy-indoleacetic acid (5-HIAA) was normal at $4.73 \mathrm{mg} / 24 \mathrm{~h}$ (reference range 2-10) and serum ACTH was slightly raised at $61 \mathrm{pg} / \mathrm{mL}(1-50)$. There were no signs of hypercortisolism. Repeat CT and ultrasound scans showed no gross evidence of residual tumour.

The patient was started on subcutaneous octreotide $150 \mu \mathrm{g}$ daily and the flushing stopped soon afterwards. Six months later, serum ACTH was normal at $20 \mathrm{pg} / \mathrm{mL}$. Subsequent values were $8 \mathrm{pg} / \mathrm{mL}$ at six months, $21 \mathrm{pg} / \mathrm{mL}$ at twenty-four months and $14 \mathrm{pg} / \mathrm{mL}$ at twenty-seven months. Over this whole period, urinary 5-HIAA remained within the normal range. Blood sugars rose with octreotide treatment, necessitating an increase in the dose of

'First Department of Internal Medicine and Nosology, University of Athens Medical School, Athens, Greece; ${ }^{2}$ Department of Medical Oncology, St Bartholomew's Hospital, London EC1 1BB, UK

Correspondence to: Dr E B Tirovola, 116-118 Aristotelous Street, 10434 Athens, Greece

E-mail: ebtirovola@hotmail.com metformin. There was still no CT or ultrasound evidence of tumour recurrence at 2 years.

\section{COMMENT}

The flushing in this patient does not appear to have been caused by excess serotonin, therefore the response to somatostatin was presumably due to suppression of some other peptide that caused the symptom. The main point of interest, however, was the early detection and treatment of ectopic ACTH secretion, which might later have caused 'occult Cushing's syndrome' and been harder to manage. ${ }^{1}$ One factor in responsiveness of ectopic ACTH secretion to somatostatin analogues (such as octreotide) is expression of somatostatin subtype 2 receptor. In certain tumours a mutation at this site engenders resistance to treatment. ${ }^{2,3}$ Another, however, is hypercortisolism; for example, in patients with untreated pituitary-dependent Cushing's disease and sustained hypercortisolism, ${ }^{4}$ somatostatin analogues do not lower the serum ACTH. In vitro, octreotide suppresses secretion of both ACTH and cortisol by corticotropic adenoma cells, in a dose-dependent manner, but this does not happen in vivo. ${ }^{5}$ A likely explanation is that, in vivo, the high cortisol down-regulates SSTR2. Another possible explanation for the ACTH response in our patient was that the treatment acted by causing tumour regression. The effect of somatostatin analogues is mainly cytostatic rather than cytotoxic, but it is noteworthy that the ascites did not recur. On balance, however, we judge that the patient's response was due to absence of the hypercortisolaemia that might later have inactivated the receptors and led to octreotide resistance. We have not seen this observation made before.

Acknowledgments We thank Mrs Sheila Mutkin for her help in the preparation of this paper.

\section{REFERENCES}

1 Burrell L, Gray CE, Thomson JA. Failure of somatostain analogue SMS 201-995 to control Cushing's syndrome due to ectopic release of ACTH from a bronchial carcinoid. Scott Med J 1989;34:553-4

2 Zhang CY, Yokogoshi Y, Yoshimoto K, et al. Point mutation of the somatostatin receptor 2 gene in the human small cell lung cancer cell line COR-L103. Biochem Biophys Res Commun 1995;210:805-15

3 Greenman Y, Melmed S. Heterogeneous expression of two somatostatin receptor subtypes in pituitary tumours. J Clin Endocrinol Metab 1994;78: 398-403

4 Hofland LJ, Lamberts SW. Somatostatin receptors in pituitary function, diagnosis and therapy. Front Horm Res 2004;32:235-52

5 Stalla GK, Brockmeier SJ, Renner U, et al. Octreotide exerts different effects in vivo and in vitro in Cushing's disease. Eur J Endocrinol 1994;130: $125-31$ 